\title{
Technology transfer of eco-holi colour preparation for income generation
}

Sunita Kale, Sangita Naik and Manisha Karhale

Received: 18.07.2018; Revised: 14.11.2018; Accepted: 27.11.2018

See end of the paper for authors' affiliations

\section{Sunita Kale}

All India Coordinated Research

Project-Home Science, Vasantrao Naik Marathwada Krishi

Vidyapeeth, Parbhani (M.S.) India

Email : sunnikale@rediffmail.

com
ABSTRACT : Holi, a festival of colours is celebrated all over India irrespective of age and gender. Synthetic Holicolors contain harmful chemicals such as oxides, glass particles and metal substances. They are dangerous to the human being as well as to the environment. As the inclination for using natural and eco-product is increasing there is a great demand for eco-colour in the market. Rural women were trained in preparation of eco-holi colours using locally available natural resources. Trained rural women had taken up the activity of eco-holi colour preparation on large scale for income generation. The colours were sold in local as well as in city markets. Through a meagre investment a very successful seasonal micro-enterprises were run by them.

KEY WORDS: Eco-holi colours, Natural dyes, Micro-entrepreneur

- HOW TO CITE THIS PAPER : Kale, Sunita, Naik, Sangita and Karhale, Manisha (2018). Technology transfer of eco-holi colour preparation for income generation. Asian J. Home Sci., 13 (2) : 642-645, DOI: 10.15740/HAS/AJHS/13.2/642-645. Copyright@ 2018: Hind Agri-Horticultural Society. 